\title{
Association of traits in Ethiopian fenugreek (Trigonella foenum-graecum L.) genotypes regarding to seed yield by using phenotypic data
}

\author{
Yimam ALI ABTEW ${ }^{1,2}$, Alemu ABATE ${ }^{3}$
}

Received October 8, 2019; accepted January 26, 2020.

Delo je prispelo 8. oktobra 2019, sprejeto 26. januarja 2020.

\begin{abstract}
Association of traits in Ethiopian fenugreek (Trigonella foenum-graecum L.) genotypes regarding to seed yield by using phenotypic data

Abstract: Shortage of information on association of traits is one of the problems in fenugreek productivity. Field experiment was implemented at Jamma district of South Wollo Administrative Zone of Amhara National Regional State, in 2018/19 main rainy season to examine the nature and extent of correlation, direct and indirect effects among yield and yield related traits. Sixty-two nationally collected fenugreek genotypes along with standard and local checks were evaluated in simple lattice design. Seed yield plot $^{-1}$ was significantly and positively correlated to biomass yield ${ }^{-1}$ $(\mathrm{r}=0.5)$ and harvest index $\left(\mathrm{r}=0.6^{* *}\right)$ at genotypic level. Seed yield was also significantly and positively correlated with harvesting index $\left(\mathrm{r}=0.6^{* * *}\right)$ and weakly and negatively $(r=-0.01)$ correlated to biomass yield at phenotypic level. Path coefficient analysis revealed that biomass (0.951), harvesting index $(0.283)$ and pod length $(-0.163)$ had contributed the maximum positive and negative direct effect on seed yield respectively, at phenotypic level. At genotypic level biomass yield ha $\mathrm{h}^{-1}(0.816)$ and harvesting index (0.930) had contributed strong positive direct effect and plant height $(-0.004)$ had revealed weak negative direct effect.
\end{abstract}

Key words: correlation; path analysis; simple lattice
Povezava med fenološkimi značilnostmi pri različnih genotipih sabljastega triplata (Trigonella foenum-graecum L.)

Izvleček: Pomanjkanje informacij o povezanosti med fenološkimi lastnostmi je eden izmed problemov pri žlahtnenju sabljastega triplata. Za preučitev neposrednih in posrednih povezav med pridelkom in fenološkimi lastnostmi pri različnih genotipih je bil na območju Jamma, južno od upravnega območja Wollo, države Amhara, Etiopija, v glavnem deževnem delu sezone 2018/19 izveden poljski poskus. 62 genotipov sabljastega triplata, zbranih po vsej državi, je bilo ob standardnih in lokalnih preverbah ovrednoteno v nepopolnem bločnem poskusu. Pridelek semena na ploskev je bil statistično značilno pozitivno povezan s pridelkom biomase $(r=0,5)$ in žetvenim indeksom $\left(r=0,6^{\star * *}\right)$ na ravni genotipa. Pridelek semena je bil statistično značilno pozitivno povezan $\mathrm{z}$ žetvenim indeksom $\left(r=0,6^{\star * *}\right)$ in $v$ šibki negativni korelaciji $(r=-0,01)$ $s$ pridelkom biomase na ravni fenotipov. Analiza neposrednih in posrednih vplivov nabora neodvisnih spremenljivk na odvisno spremenljivko je pokazala, da so biomasa $(0,951)$, žetveni indeks $(0,283)$ in dolžina stroka $(-0,163)$ prispevali največji pozitivni in negativni neposredni učinek na pridelek zrnja na fenotipski ravni. $\mathrm{Na}$ genotipski ravni sta imela pridelek biomase na hektar $(0,816)$ in žetveni indeks $(0,930)$ močan, pozitivni neposredni učinek, višina rastlin je imela šibek neposredni negativni učinek $(-0,004)$ na pridelek.

Ključne besede: korelacija; analiza posrednega in neposrednega vpliva; nepopolni bločni poskus

1 Amhara Agricultural Research Institute, Sirinka Agricultural Research Center, Woldia, Ethiopia

2 Corresponding author, e-mail: yimamali121102@gmail.com

3 Bahir Dar University, College of Agriculture and Environmental Science, Bahir Dar, Ethiopia 


\section{INTRODUCTION}

Fenugreek (Trigonella foenum-graecum L.) is an annual plant in the family Fabaceae, with leaves consisting of three small obovate to oblong leaflets. It is believed that fenugreek is native to Mediterranean region (Petropoulos, 2002). Correlation measures the mutual association between two variables but does not indicate the cause and effect relationship of traits contributing directly or indirectly towards economic yield (Shivanna et al., 2007). The value of correlation coefficient, which is a ratio of the covariance between the two variables and the geometric mean of their variances, ranges from -1 to +1 , the extreme values indicating perfect negative and positive association, respectively (Gomez and Gomez, 1984). The correlations between characters indicate that the gene for the traits are either linked or are influenced by the same differences of environmental conditions (Falconer and Mackay, 1996).

Phenotypic correlation is the observable correlation between two variables; it includes both genotypic and environment effects and genotypic correlation on the other hand is the inherent association between two variables; it may be either due to a pleiotropic action of genes, linkage or, more likely both (Singh, 1993). Environment plays an important role in correlation. In some cases, environment affects two traits simultaneously in the same direction or sometimes in different directions. Genetic and environmental causes of correlation combine together and give phenotypic correlation. The dual nature of phenotypic correlation makes it clear that the magnitude of genetic correlation cannot be determined from phenotypic correlation (Usman et al., 2006). Correlation coefficient analysis helps to determine the nature and degree of relationship between any two measurable characters. Knowledge of the correlations that exist between important characters may facilitate the interpretations of the results that are already obtained, and provides the basis for planning more efficient breeding program. However, as the number of independent variables influencing a particular dependent variable, a certain amount of interdependence is expected (Aryo et al., 1973).

Mevlut et al. (2008) stated that correlation analyses are being widely used in many crop species by plant breeders to understand the nature of complex interrelationships among traits and to identify the sources of variation in yield. Yield is a quantitatively inherited trait; its expression is an outcome of complex interaction of several genes and environment. Therefore, proper understanding of association of different traits provides more reliable criterion for selection to achieve the goal of high yield (Mohammad et al., 2001). High yield through yield attributes, as primary interest in crop improvement, re- quires understanding the magnitude of correlations among various yield traits (Tadele Taddese et al., 2009).

Yield is the result of yield-correlated characters and some other undefined factors. Yield contributing traits can be ranked and specific characters producing a given correlation can be observed through path coefficient analysis (Ariyo et al., 1973). Therefore, the use of path coefficient analysis is important to come up with meaningful results of cause and effect. Therefore, this research is conducted to examine the nature and extent of correlation, direct and indirect effects among yield and yield related traits.

\section{MATERIALS AND METHODS}

\subsection{DESCRIPTION OF THE EXPERIMENTAL SITE}

The experiment was conducted at Jamma research site of Sirinka Agricultural Research Center (SARC) at Jamma district during the growing season of 2018. Jamma is located at $10^{\circ} 27^{\prime} \mathrm{N}$ and $39^{\circ} 16^{\prime} \mathrm{E}$ on an altitude of 2622 meters above sea level, South Wollo, Amhara National Regional State, Ethiopia. Based on the last ten years (2008-2017) meteorological data obtained from Ethiopian Meteorological Agency, Kombolcha station, Jamma receives an average annual rainfall of $1047 \mathrm{~mm}$ and minimum and maximum temperature of $9.2^{\circ} \mathrm{C}$ and $26.2^{\circ} \mathrm{C}$, respectively. Jamma is $120 \mathrm{~km}$ and $320 \mathrm{~km}$ away from Dessie and Addis Ababa, respectively.

\subsection{EXPERIMENTAL MATERIALS, DESIGN AND PROCEDURE}

Sixty-two fenugreek accessions collected from Debre-Zeit Agricultural Research Center (DZARC) along with local and standard checks were evaluated at Jamma testing site of SARC. The experiment was laid out using simple lattice design $(8 \times 8)$ on plot size of $1.6 \mathrm{~m}^{2}$, with an inter-row of $20 \mathrm{~cm}$ and intra-row spacing of $5 \mathrm{~cm}$. The accessions were collected from different parts of the country.

Clean fenugreek seeds were sown at distances of 20 and $5 \mathrm{~cm}$ between rows and plants, respectively, as per the national recommendation. Each genotype grew on a gross plot size of $1.6 \mathrm{~m}^{2}(0.8 \mathrm{~m}$ width $\times 2 \mathrm{~m}$ length). The distances between plots and blocks were $0.5 \mathrm{~m}$ and $1 \mathrm{~m}$, respectively. Being fenugreek is leguminous crop, fertilizer was not applied at all. Weeding and thinning were carried out at the appropriate time. Data were obtainerd from the central two rows with net plot size of $0.8 \mathrm{~m}^{2}$ $(0.4 \mathrm{~m} \times 2 \mathrm{~m})$. 
Table 1: Passport data of accessions

\begin{tabular}{|c|c|c|c|c|c|c|c|}
\hline S.no & Accession Number & Region & Zone & S.no & Accession Number & Region & Zone \\
\hline 1 & 53003 & Oromiya & N/Shewa & 33 & 201627 & NA & \\
\hline 2 & 53008 & Amhara & S/ Gondar & 34 & 201632 & NA & \\
\hline 3 & 53009 & Amhara & S/Gondar & 35 & 202121 & NA & \\
\hline 4 & 53014 & Amhara & S/ Wollo & 36 & 202122 & NA & \\
\hline 5 & 53016 & Oromiya & W/ Harerge & 37 & 202124 & NA & \\
\hline 6 & 53021 & Amhara & E/Gojam & 38 & 202125 & NA & \\
\hline 7 & 53023 & Oromiya & N/ Shewa & 39 & 202126 & NA & \\
\hline 8 & 53026 & Amhara & E/Gojam & 40 & 202127 & NA & \\
\hline 9 & 53027 & Amhara & E/Gojam & 41 & 202129 & NA & \\
\hline 10 & 53028 & Amhara & E/Gojam & 42 & 202132 & NA & \\
\hline 11 & 53035 & Amhara & E/Gojam & 43 & 202133 & NA & \\
\hline 12 & 53037 & Amhara & E/Gojam & 44 & 207361 & Amhara & S/ Gondar \\
\hline 13 & 53039 & Amhara & E/Gojam & 45 & 207362 & Amhara & N/ Gondar \\
\hline 14 & 53040 & Amhara & E/Gojam & 46 & 207363 & Amhara & N/Gondar \\
\hline 15 & 53041 & Amhara & E/Gojam & 47 & 207364 & Amhara & N/ Gondar \\
\hline 16 & 53042 & Amhara & E/Gojam & 48 & 207365 & Amhara & N/ Gondar \\
\hline 17 & 53045 & Amhara & E/Gojam & 49 & 207390 & Amhara & N/Gondar \\
\hline 18 & 53055 & Amhara & E/Gojam & 50 & 207391 & Amhara & S/ Gondar \\
\hline 19 & 53056 & Amhara & E/Gojam & 51 & 207394 & Amhara & S/ Gondar \\
\hline 20 & 53057 & Amhara & E/Gojam & 52 & 208680 & Oromiya & E/ Harerge \\
\hline 21 & 53058 & Amhara & E/Gojam & 53 & 210864 & NA & \\
\hline 22 & 53059 & Amhara & E/ Gojam & 54 & 212549 & Amhara & N/ Shewa \\
\hline 23 & 53080 & Amhara & E/ Gojam & 55 & 212552 & Amhara & N/ Shewa \\
\hline 24 & 53085 & Oromiya & Bale & 56 & 212777 & Amhara & E/ Gojam \\
\hline 25 & 53086 & Oromiya & N/Shewa & 57 & 213115 & Amhara & S/ Wollo \\
\hline 26 & 53094 & SNNP & S/Omo & 58 & 213116 & Amhara & S/ Wollo \\
\hline 27 & 53097 & Amhara & E/ Gojam & 59 & 214942 & Amhara & N/ Shewa \\
\hline 28 & 53098 & Amhara & E/ Gojam & 60 & 215056 & Oromiya & Borena \\
\hline 29 & 53099 & Amhara & E/ Gojam & 61 & 216898 & Oromiya & Arssi \\
\hline 30 & 53106 & Amhara & N/ Shewa & 62 & 216899 & Oromiya & Arssi \\
\hline 31 & 53108 & Amhara & N/Gondar & 63 & Jamma & & \\
\hline 32 & 201577 & NA & & 64 & Local & & \\
\hline
\end{tabular}

$\mathrm{NA}=$ not identified

\subsection{DATA COLLECTION}

The following data were recorded from the central two rows, leaving a guard row from both sides of the plot either plot or plant basis's.

Days to 50 \% flowering: days to $50 \%$ flowering was recorded as the number of days from planting to the time when $50 \%$ of the plants in the plots produced flower.

Days to $90 \%$ maturity: was recorded as number of days from planting to the time when $90 \%$ of the plants in the plot reach physiological maturity.

Pod filling period: number of days from flowering or exertion of pods to the time when $50 \%$ of the pod forms seeds.

Biomass yield (above ground): it was taken as the total above-ground biomass weight of the plants from the central two rows. Total above-ground biomass was harvested and sun-dried and weighed using spring balance 
Seed yield: it was taken from the central two rows. Entire plants were harvested, threshed and winnowed. Clean seed were measured using electronic sensitive balance.

Thousand seeds mass: thousand seeds were counted and weighed using electronic sensitive balance for each replication.

Harvesting index: it was calculated as the ratio of seed yield to biomass yield in percent

Plant height: plant height was measured from the main stem, measured from the ground level to the tip of the plant using measurement tape at $90 \%$ physiological maturity.

Pod length: pod length was measured from the tip to petiole of the pod at $90 \%$ physiological maturity.

Number of branches per plant: the total number of branches arising from the main stem was counted at $90 \%$ physiological maturity.

Number of pods per plant: the total number of pods per plant was counted at physiological maturity.

Number of seeds per pod: the total number of seeds per pod was counted at physiological maturity.

\subsection{DATA ANALYSES}

Correlations (genotypic and phenotypic) and path coefficient analysis were analyzed using SAS statistical software package, version 9.0 as per Gomez and Gomez (1984).

\subsection{PHENOTYPIC AND GENOTYPIC CORRELA- TION COEFFICIENTS}

Phenotypic correlation, the observable correlation between two variables, which includes both genotypic and environmental components between two variables, was estimated using the formula suggested by Miller et al. (1958).

The calculated value was compared with the tabulated ' $t$ ' value at $5 \%$ or $1 \%$ level of significance for both phenotypic and genotypic correlations.

\subsection{PATH COEFFICIENT ANALYSIS}

Associations of yield with its components were estimated using correlation and path analysis. The use of path analysis requires a cause and effect situation among the variables. Path coefficient analysis is calculated using the formula suggested by Dewey and LU (1959) to assess direct and indirect effects of different traits on seed yield as:

$$
r_{i j}=p_{j}+\sum r_{i k} p_{k j}
$$

Where $r_{i j}$ is mutual association between the independent traits (i) and the dependent trait (j) as measured by the correlation coefficient, $\mathrm{p}_{\mathrm{ij}}$ is component of direct effect of the independent trait (i) on the dependent variable (j); and $r_{i k} p_{k j}$ is the components of indirect effect of a given independent trait (i) on the dependent traits $(j)$ via all other independent traits $(\mathrm{k})$.

\section{RESULT AND DISCUSSION}

\subsection{CORRELATION COEFFICIENT ANALYSIS}

Yield is a complex character governed by several other yield attributing characters. Since, most of the yield attributing characters are quantitatively inherited and highly affected by environment, it is difficult to judge whether the observed variability is heritable or not. Correlation studies are helpful in determining the components of complex traits like yield. The correlation coefficient is the measures of degree of symmetrical association between two traits and helps us in understanding the nature and magnitude of association among yield and yield components. Association between any two traits or among various traits is of immense importance to make desired selection of combination of traits (Ahmad et al., 2003). Therefore, phenotypic and genotypic correlation coefficients were estimated for all pairs of traits and results are presented in Table 2.

The magnitudes of genotypic correlation coefficients for most of the characters were higher than their corresponding phenotypic correlation coefficients, except few cases, which indicate the presence of inherent or genetic association among various characters. The degree of association between two characters was measured by the correlation coefficient.

Phenotypically seed yield had weak to strong positive correlation with days to flowering, pod filling period, plant height, number of branch per plan, number of pod per plant, harvesting index and thousand seed mass $\left(\mathrm{r}=0.18,0.119,0.129,0.115,0.222,0.6^{* * *}\right.$ and 0.158 respectively). While weak and negatively correlated with days to maturity, biomass yield, number of seed per pod and pod length $(\mathrm{r}=-0.04,-0.02,-0.08$ and -0.08 respectively). Harvesting index revealed very highly significance strong negative and positive phenotypic correlation with biomass yield and seed yield $\left(r=-0.6^{* * *}\right.$ and 
$\left.0.6^{* * *}\right)$ respectively. It also strongly negative correlated with biomass $\left(\mathrm{r}=-0.8^{* * *}\right)$ and weakly correlated with the rest traits. Biomass yield had only weak positive phenotypic correlation with pod filling period and plant height, while it correlates negatively and weakly with the rest traits except harvesting index. Pod length revealed significance positive and negative phenotypic correlation with plant height and number of seed per plant and date of maturity $\left(\mathrm{r}=0.31^{\star}, 0.43^{\star *}\right.$ and $\left.-0.26^{\star}\right)$ respectively. Plant height had positive significance positive phenotypic correlation with number of branches $\left(\mathrm{r}=0.3^{*}\right)$.

Therefore, phenotypically traits like number of pods plant $^{-1}$, plant height, pod length and harvesting index could be utilized in breeding program to improve fenugreek genotypes for higher yield. Selection simultaneously based on these characters would be effective and a worthwhile for increasing seed yield and can be taken as primary selection criteria in fenugreek.

Genotypically seed yield revealed positive and significance correlation with biomass and harvesting index $\left(\mathrm{r}=0.5^{* *}\right.$ and $\left.0.6^{* * *}\right)$. It is also weak negatively correlated with days to maturity, pod filling period and number of seed per plant, while weak and positive correlation with the rest of the traits. Pod length had positive significance genotypic correlation with days to flowering and negative significance with days to maturity and plant height $\left(\mathrm{r}=0.4^{* *},-0.29^{\star}\right.$ and $\left.-0.25^{\star}\right)$. Number of seed per plant had strong significance negative correlation with thousand seed mass $\left(r=-0.4^{\star *}\right)$, while number of branches had strong positive correlated with plant height and negatively significant correlated with pod filling period $\left(\mathrm{r}=0.5^{\star \star}\right.$ and $\left.-0.28^{\star}\right)$. Biomass yield revealed positively correlated with all traits except days to maturity. Generally genotypic correlation was higher magnitude than their phenotypic correlation and most traits weakly correlated to each other. Therefore, genotypically improving of biomass yield and harvesting index will leads to develop high yielding fenugreek genotypes. Generally, in the present study, seed yield revealed strong positive correlations with harvesting index both at genotypic and phenotypic levels, implying pleiotropic effect of harvesting index with seed yield. Hence, selection genotypes having high harvesting index would improve seed yield of fenugreek. Biomass yield also affected seed yield positively and significantly at genotypic level.

In agreement with Mahendra (2015) reported, negative and weakly phenotypic correlation was achieved between days to flowering to number of branches per plant, number of seeds per plant, pod length and thousand seed mass, while opposite in level of significance and relation of days to flowering with plant height and harvesting index. Krishan et al. (2013) reported seed yield had positive correlation with plant height, number of seed plant ${ }^{-1}$ and number of branch per plant at both levels. Betelhiem Belete (2018) also reported similarly in days to flowering to days to maturity, thousand seed mass to days to flowering, days to flowering to seed yield, seed yield to thousand seed mass and days to flowering to number of seed plant ${ }^{-1}$ both at phenotypic and genotypic level. Anbuha et al. (2013) also reported similar result that positive correlation with days to flowering to number of pods plant $^{-1}$ at genotypic level, significant negative and positive correlation with days to flowering to pod length and plant height to number of pods plant ${ }^{-1}$ at genotypic and phenotypic level respectively and number of seed plant ${ }^{-1}$ had positive correlation to plant height both at genotypic and phenotypic level.

\subsection{PATH COEFFICIENT ANALYSIS}

Path coefficient analysis was computed to estimate the contribution of individual characters to seed yield. It is performed to understand the causes and effects of chain relationships of different yield contributing characters with yield. The path coefficient analysis was conducted using seed yield as dependent variable and all other traits studied as independent variables. The results of phenotypic and genotypic path coefficient analysis are presented in Table 3 and 4 below.

\subsection{PHENOTYPIC DIRECT AND INDIRECT EF- FECTS OF OTHER TRAITS ON SEED YIELD}

Correlation coefficients were further partitioned into direct and indirect effects. Biomass yield (0.95) had exerted the highest positive direct effects on seed yield. Plant height (0.15), number of branches per plant (0.05), thousand seed mass (0.07) and harvesting index (0.28) exerted positive direct effects on seed yield (Table 3 ). High values of direct effects suggested that the true relationship and direct selection for these traits may also increase and give better response for improvement of seed yield and can be major selection criteria in fenugreek breeding programs. Number of pods per plant $(-0.14)$, number of seeds per pod $(-0.01)$ and pod length $(-0.16)$ on the other hand, exerted negative phenotypic direct effect and unfavourable effect on seed yield (Table 3). The negative phenotypic direct effects on seed yield indicated that selection for these traits would not be rewarding for yield improvement. The direct effect of biomass yield (0.95) and number of pods per plant (-0.014) but their association to seed yield was $(\mathrm{r}=-0.14$ and 0.12$)$ opposite in direction. Indicating that fenugreek genotypes having maximum biomass yield and number of pods would 


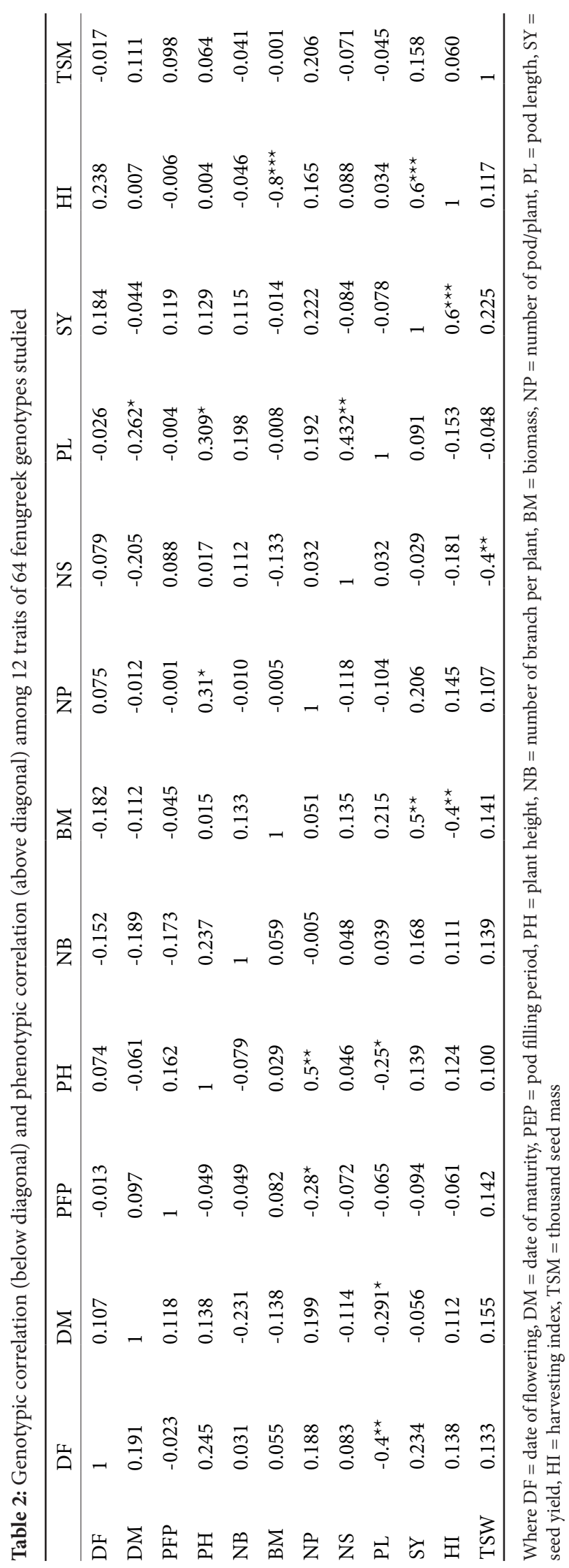


Table 3: Estimates of direct (bold diagonal) and indirect effect (off diagonal) at phenotypic level 8 characters on seed yield in fenugreek genotypes

\begin{tabular}{lllllllll}
\hline & PH & NB & BM & NP & NS & PL & HI & TSM \\
\hline PH & $\mathbf{0 . 1 4 8 7}$ & 0.0115 & 0.0144 & -0.0044 & 0.0000 & -0.0504 & 0.0051 & 0.0045 \\
NB & 0.0352 & $\mathbf{0 . 0 4 8 6}$ & 0.1263 & 0.0001 & -0.0003 & -0.0324 & -0.0596 & -0.0029 \\
BM & 0.0022 & 0.0065 & $\mathbf{0 . 9 5 1 1}$ & 0.0001 & 0.0003 & 0.0013 & -0.9757 & -0.0001 \\
NP & 0.0460 & -0.0005 & -0.0048 & $\mathbf{- 0 . 0 1 4 1}$ & -0.0001 & -0.0313 & 0.2121 & 0.0142 \\
NS & 0.0025 & 0.0054 & -0.1264 & -0.0004 & $-\mathbf{0 . 0 0 2 3}$ & -0.0706 & 0.1128 & -0.0049 \\
PL & 0.0459 & 0.0097 & -0.0073 & -0.0027 & -0.0010 & $-\mathbf{0 . 1 6 3 2}$ & 0.0439 & -0.0031 \\
HI & 0.0006 & -0.0023 & -0.7231 & -0.0023 & -0.0002 & -0.0056 & $\mathbf{0 . 2 8 3 3}$ & 0.0042 \\
TSM & 0.0096 & -0.0020 & -0.0007 & -0.0029 & 0.0002 & 0.0073 & 0.0776 & $\mathbf{0 . 0 6 9 2}$ \\
\hline
\end{tabular}

$\mathrm{PH}=$ plant height, $\mathrm{NB}=$ number of branches per plant, $\mathrm{BM}=$ biomass, $\mathrm{NP}=$ number of pod/plant, $\mathrm{PL}=$ pod length, $\mathrm{SY}=$ seed yield, $\mathrm{HI}=$ harvesting index, TSM $=$ thousand seed mass.

negatively affect seed yield, therefore; keeping other traits constant, selection of fenugreek genotypes having average amount biomass yield and number of pods would improve seed yield in fenugreek breeding.

Number of seeds per pod exerted the highest positive phenotypic indirect effect on seed yield through harvesting index. Number of seed per plant through harvesting index and pod length through plant height exerted second and third highest positive indirect effect on seed yield. While the first and second highest negative phenotypic indirect effect on seed yield exerted by biomass yield $(-0.96)$ through harvesting index and harvesting index $(-0.723)$ through biomass yield. Genetic improvement in seed yield can be accelerated if this phonological attribute is used as selection criteria. For this purpose, it is necessary not only to identify indirect linkage to seed yield potential, but also to improve the understanding of the genetic basis controlling this trait for easy handling (Garcia et al., 2011). Harvesting index had indirect and positive effect on seed yield through plant height and thousand seed mass and harvesting index had indirect negative effects was exhibited via number of branches per plant, biomass yield, number of pods, number of seeds per plant and pod length. The high positive direct magnitude effect of biomass yield on seed yield was counter balanced by high negative indirect effect on seed yield through harvesting index. The results of phenotypic path coefficient analysis revealed that pod length exerted positive indirect effects on seed yield through biomass yield and harvesting index and negative indirect effect in plant height, number of branches per plant, number of pods per plant, number of seeds per pod and thousand seed mass (Table 3). negative indirect effect of biomass yield on seed yield was observed through thousand seed mass and harvesting index that cannot be generalized as traits for indirect selection for higher grain yield improvement.
Therefore, plant height, biomass yield and harvesting index could be used as indirect selection criteria for developing high yielding fenugreek variety.

In agreement with the current findings, Ali et al. (2012) also reported positive direct effects of harvest index and biological yield on seed yield. Analogous magnitude of path result was reported by Mahendra et al. (2015) that harvesting index, number of branches per plant and thousand seed mass revealed positive direct effect and number of seeds per plant and number of pod and revealed negative direct effect on seed yield, while opposite result in plant height and pod length.

\subsection{GENOTYPIC DIRECT AND INDIRECT EF- FECTS OF OTHER TRAITS ON SEED YIELD}

The genotypic association between dependant and independent traits was explained by the genotypic path coefficient analysis method. Number of branches per plant (0.01), number of seeds per plant (0.04), biomass yield (0.82), number of pods plant ${ }^{-1}(0.04)$, thousand seeds mass (0.01) and harvesting index (0.93) exerted positive genotypic direct effects on seed yield, while plant height had negative direct effects on seed yield (Table 4).

The genotypic correlations of biomass yield plot $^{-1}$, pod length and harvesting index on seed yield were almost equal to their corresponding genotypic direct effect indicating that genotypic correlation coefficient explained true relationship between them. The highest indirect positive genotypic effect was recorded on pod length $\left(r_{g}=0.18\right)$ through biomass yield, while the highest negative indirect effect on seed yield was biomass yield $\left(r_{g}=-0.39\right)$ through harvesting index. The minimum negative direct effect of plant height on seed yield was counterbalanced by significant positive correlation 
Table 4: Estimates of direct (bold diagonal) and indirect effect (off diagonal) at genotypic level for 8 characters on seed yield in fenugreek genotypes

\begin{tabular}{lllllllll}
\hline & PH & NB & BM & NP & NS & PL & HI & TSM \\
\hline PH & $\mathbf{- 0 . 0 0 4 4}$ & -0.0008 & 0.0234 & 0.0178 & 0.0016 & -0.0150 & 0.1151 & 0.0012 \\
NB & 0.0003 & $\mathbf{0 . 0 1 0 7}$ & 0.0484 & -0.0002 & 0.0017 & 0.0023 & 0.1029 & 0.0016 \\
BM & -0.0001 & 0.0006 & $\mathbf{0 . 8 1 5 8}$ & 0.0020 & 0.0048 & 0.0127 & -0.3906 & 0.0017 \\
NP & -0.0019 & 0.0000 & 0.0414 & $\mathbf{0 . 0 4 0 4}$ & -0.0042 & -0.0062 & 0.1349 & 0.0013 \\
NS & -0.0002 & 0.0005 & 0.1103 & -0.0047 & $\mathbf{0 . 0 3 5 5}$ & 0.0019 & -0.1685 & -0.0042 \\
PL & 0.0011 & 0.0004 & 0.1754 & -0.0042 & 0.0011 & $\mathbf{0 . 0 5 9 2}$ & -0.1419 & -0.0006 \\
HI & -0.0005 & 0.0012 & -0.3424 & 0.0059 & -0.0064 & -0.0090 & $\mathbf{0 . 9 3 0 4}$ & 0.0014 \\
TSM & -0.0004 & 0.0015 & 0.1150 & 0.0043 & -0.0128 & -0.0028 & 0.1089 & $\mathbf{0 . 0 1 1 8}$ \\
\hline
\end{tabular}

$\mathrm{PH}=$ plant height, $\mathrm{NB}=$ number of branches per plant, $\mathrm{BM}=$ biomass, $\mathrm{NP}=$ number of pod/plant, $\mathrm{PL}=$ pod length, $\mathrm{SY}=$ seed yield, $\mathrm{HI}=$ harvesting index, TSM=thousand seed mass.

between plant height and number of pods per plant. This implies maximum number of branches per plant, biomass yield, number of pods per plant, harvesting index, thousand seed mass and number of seeds per pod will improve seed yield of fenugreek genotypes.

The indirect effect of plant height through biomass yield (-0.0001), number of seeds per pod (-0.0002), number of pods per plant $(-0.02)$, harvesting index $(-0.0005)$ and thousand seed mass (-0.0004) counter balanced the direct effect of plant height on seed yield per plot and resulted in the correlation coefficient of 0.12 . It was noted that, even if the indirect influence of plant height on seed yield per plot through the above mentioned characters was too small (negative), their cumulative effect (the direct effect of plant height with seed yield) is high, therefore all those traits, were considered in selection. Anubha et al. (2013) reported similar result that positive genotypic direct effect on seed yield through number of pods plant ${ }^{-1}$, number of seeds per plant and thousand seed mass, while opposite result revealed on genotypic direct effect of plant height and pod length on seed yield. Pushpa (2010) also reported that number of branches had positive indirect effect on seed yield through number of seeds per plant, biomass yield and harvesting index and negative indirect effect of number of branches via number of pods per plant. In contrast to this finding Betelheim Belete (2018) reported that genotypically plant height exerted positive direct effect on seed yield plot $^{-1}$, while number of pods per plant and number seeds plant $^{-1}$ had negative direct effect on seed yield.

\section{CONCLUSION}

Ethiopian fenugreek genotype traits showed very highly significant difference in between. Biomass and harvesting index have high magnitude of direct effect on productivity of fenugreek yield. Number of seeds per pod and number of pods per plant through harvesting index also have high indirect effects on productivity of fenugreek. Generally, indirect selection of genotypes based on high mean values of these positive significantly correlated and high positive direct effect traits will be used to improve the productivity of fenugreek. In addition, by selecting genotypes having medium mean negative values of association will be used to increment of the productivity of fenugreek.

\section{ACKNOWLEDGEMENTS}

The authors acknowledge Amhara Agricultural Research Institute (AARI) and Sirinka Agricultural Research Center for financial support.

\section{REFERENCES}

Abdul Q., Niaz A., Sohail A., Malik A., Haris K., Aamir N., and Faiz U. (2017). Characterization of agro-morphological variation in exotic fenugreek (Trigonella foenum-graecum L.) germplasm. Journal of Biodiversity and Environmental Sciences, 10(3), 71-79.

Ahmad, M., F. Mohammed, K. Maqbool, A. Azamand and S. Iqbal. (2003). Genetic variability and traits correlation in wheat. Sarhad Journal of Agriculture, 19(3), 347-351.

Anubha, J., Singh, B., Solanki, R. K., Saxena, S.N. and Kakani R.K. (2013). Genetic variability and character association in fenugreek (Trigonella foenum-graecum L.). International Journal of. Seed Spices, 3(2), 22-28.

Ariyo OJ, Aknova ME. And Fatokun C.A. 1973. Plant characters correlation and path coefficient analysis of pod yield in Okra. Euphytica, 36, 677-686. https://doi.org/10.1007/ BF00041518

Betelehiem Belete. (2018). Genetic variation for yield and yield 
related traits of fenugreek (Trigonella foenum-graecum L.) genotypes in North Shewa. M.Sc Thesis, Haramaya University, Ethiopia.

Dewey, DR, and Lu KH. (1959). A Correlation and path coefficient analysis of components of crested wheat-grass seed production. Agronomy Journal, 15, 515-518. https://doi. org/10.2134/agronj1959.00021962005100090002x

Falconer, D.S. and Mackay, T.F.C. (1996). Introduction to quantitative genetics. Fourth edition. Longman group Ltd, England, pp 312.

Gomez, K. A. and Gomez A. A., (1984). Statistical Procedure for Agricultural Research. $2^{\text {nd }}$ edition. John Wiley and Sons, Inc. USA. 680.

Krishan Pal Singh, Beena Nair, Jain P. K. and Sengupta S. K. (2013). Correlation studies in fenugreek (Trigonella foenum-graecum L.). African Journal of Agriculture, 8(38), 4773-4779.

Mahendra Gurjar, I.S. Naruka, R.P.S. Shaktawat. (2015). Variability and correlation analysis in fenugreek (Trigonella foenum-graecum L.). Legume Research- An International Journal, 39(3), 459-465. https://doi.org/10.18805/lr.v0iOF.9286

Mevlut T., C. Necmettin C., Gamze B. and Emine B. (2008). Relationships between seed yield and yield components in narbon bean (Vicia narbonensis L.) by path analysis. Bangladesh Journal of Botany, 37(1), 27-32. https://doi. org/10.3329/bjb.v37i1.1560

Miller, P.A., C. Williams C., Robinson H.F. and Comstock R.E. (1958). Estimates of genotypic and Environmental variances and co-variances in upland cotton and their implications in selection. Agronomy Journal, 50, 126 -131. https:// doi.org/10.2134/agronj1958.00021962005000030004x
Mohammad, A., Noor-ul I. and Khalid MS. (2001). Correlation and path coefficient studies in linseed. Journal of Biological Science, 1(6), 446-447. https://doi.org/10.3923/ jbs.2001.446.447

Petropoulos GA. (2002). Fenugreek. The genus Trigonella. Taylor \& Francis, London and New York, 255. https://doi. org/10.4324/9780203217474

Pushpa, TN., Chandregowda, M., Gouda, M.A.P., Srikantaprasad, D. and Anupa T. (2010). Genetic evaluation of fenugreek (Trigonella foenum-graecum L.) for growth and seed yield attributes. Journal of Asian Horticulture, 6(2), 33-37.

Robertson, G.E. (1959). The sampling variance of genetic correlation coefficient. Biometrics, 15, 469-485. https://doi. org/10.2307/2527750

Sharma, J.1998. Statistical and biometrical techniques in plant breeding. New Age International (P) limited, publishers. New Delhi. 432.

Shivanna, J., Ravi, C. S., Sreeramu, B. S. (2007). Character association and path coefficient analysis among economic traits in Makoi(Solanum nigrum L.). Karnataka Journal of Agricultural Science, 20(3), 575-577.

Singh, B. D. (1993). Plant Breeding, Principles and Methods. Kalyani Publishers, New Delhi, 103-142.

Tadele Tadesse, Harjit, S. and Bulcha Weyessa. (2009). Correlation and path coefficient analysis among seed yield traits and oil content in Ethiopian linseed germplasm. Journal of Sustainable Crop Production, 4(4), 8-16.

Usman, S., Thsan, K., Tariq, M. and R. Muhammad. (2006). Correlation coefficients between yield and yield components in wheat. Journal of Agriculture Research, 44(1), 1-8. 